\title{
THE OPERATIONAL RISK MANAGEMENT IN THE ROMANIAN SMES
}

\author{
Roxana Mironescu \\ "Vasile Alecsandri” University of Bacau \\ roxy_mironescu58@yahoo.com \\ Ovidiu Leonard Turcu \\ "Vasile Alecsandri” University of Bacau \\ ovidiuturcu@ymail.com \\ Costel Ceocea \\ "Vasile Alecsandri" University of Bacau \\ costelceocea@yahoo.comt
}

\begin{abstract}
The prerequisite for the smooth functioning of the business risk management is the correct identification. Basically, identifying business risks is fundamental to determine the optimal level of protection for a given activity. If the risk is underestimated, the protection will be insufficient to cover losses and, if overstated, the cost of protection will reduce the excess proceeds of the activity. The objective of this research was to identify the internal and external major factors which influence the present activities and the future of the SMEs from the North East region The method used in this paper work is based on a questionnaire applied to a sample of 120 top managers coming from various fields of activity, operating on the market for more than two years. The management of information and the data collection was conducted in the late 2013. In the first stage, a total of 35 risks was identified. The further evaluation of the results used the probability and the impact of the identified risks, based on questionnaires and by processing information from the documentation provided by the managers of SMEs taken under the analysis.
\end{abstract}

\section{Keywords}

corporate governance; financing risks; financial predictions market risks; operational risks

\section{JEL Classification}

M10

\section{Introduction}

The study of risks is born, as a science, in the sixteenth century a period of time of renaissance for challenges and discoveries. Today, risk management has penetrated the entire spectrum of activities, as a discipline that measures the degree to which the consequences of failures, the irregularities or mistakes lead to huge depreciation and disaster, damaging the rights and objectives of certain relevant stakeholders.

As part of the investment risk control, specialists have discovered the full range of risks grouped in three main areas, these are the risks: credit, market and operational.

The operational risk refers to the exposure of the financial losses due to downtime or lack of the correlation of the internal activities of an entity, due to events, trends or external changes that could not be known and preventable or to the internal organization and control system and ethical standards set excluding those events that are specific to market risk, credit risk and the strategic. Elements of operational risk are determined by the existence of risks of personnel, procedural risks, technological and transaction control. The participants in investment and in operational processes are all agreed that operational risk cannot be completely eliminated and the work must be conducted such 
that its results be as small negative as possible. Starting from the fact that any economic entity is created in order to profit from the production and sale of goods or services, the results are based on the organization and management of the entire process of capitalizing the available assets, borrowed or attracted. The operating with business assets, reflected by the indicator net income will fluctuate, depending on the entity's ability to market the produced goods and services. In the development of business, the company assumes the execution of multiple processes that have their own risks and during these operations they are subject to operational risk, caused by defects, errors, operating or technical operations.

The definition of the operational risks has preoccupied, in that recent years, financial specialists who, meeting in the Basel Committee in 1998, have defined and framed at last the operational risk investment purposes named the protection against this risk:

- $\quad$ Avoiding the unpredictable huge losses;

- Avoiding the multitude of small and dangerous losses;

- Improving the operational efficiency;

- Improving the profit on the invested capital unit;

- Reduction of earnings volatility;

- A more efficient allocation of the capital;

- Improving the customer satisfaction;

- Improving the managers' preoccupation about the operational risks;

- A better usage of the intellectual capital of the firm;

- Ensuring the company manager and shareholders that these risks are properly assumed.

In a business environment, the action of conducting risk management contains the entire combination of strategies, processes, infrastructure and institutions able to furnish appropriate models that help control as strict as possible, so the risk may depend on its purpose, so that:

- To correctly identify all the potential risks, the company may encounter;

- To elaborate and develop adequate measurement and control procedures, establishing also the upper limit of the risk bearable by the company (risk appetite);

- To use in the internal processes those methods and techniques the most advanced, used by the modern economic entities in the same field of activity;

- To continuously adapt the operational system to the market conditions, in a transparent manner;

- To pay attention to the existence of favorable clauses or to propose such favorable specific clauses for the titles transactions;

- To apply and propose particular models conforming to those of the economic entity.

Table 1. The managing process of the operational risk

\begin{tabular}{|c|c|c|c|c|}
\hline Environment & Strategy & Processes & Infrastructure & Models \\
\hline Culture & $\begin{array}{c}\text { The } \\
\text { activity } \\
\text { purpose }\end{array}$ & $\begin{array}{c}\text { Risk } \\
\text { awareness }\end{array}$ & $\begin{array}{c}\text { The firm and } \\
\text { its people }\end{array}$ & $\begin{array}{c}\text { The particular } \\
\text { social and cultural }\end{array}$ \\
\hline Training & Risk & $\begin{array}{c}\text { Evaluation } \\
\text { and action }\end{array}$ & $\begin{array}{c}\text { Politics and } \\
\text { procedures }\end{array}$ & $\begin{array}{c}\text { The lowest } \\
\text { training level }\end{array}$ \\
\hline Communications & $\begin{array}{c}\text { Proposed } \\
\text { values }\end{array}$ & $\begin{array}{c}\text { Operating } \\
\text { modus }\end{array}$ & Methodologies & Organization \\
\hline acceptable & $\begin{array}{c}\text { Measurement } \\
\text { and control }\end{array}$ & $\begin{array}{c}\text { Control and } \\
\text { limits }\end{array}$ & $\begin{array}{c}\text { Transparency and } \\
\text { impartiality }\end{array}$ \\
\hline
\end{tabular}




\begin{tabular}{|c|c|c|c|c|}
\hline & $\begin{array}{c}\text { limit of } \\
\text { the risk }\end{array}$ & & & \\
\hline Wages & - & $\begin{array}{c}\text { Measuring } \\
\text { the value }\end{array}$ & System & $\begin{array}{c}\text { Optimal } \\
\text { compensation }\end{array}$ \\
\hline
\end{tabular}

From the analysis of the risk management process, it seems that three fundamental components are required:

- $\quad$ identification and risk assessment;

- develop a strategy for responding to risk factors and;

- the risk control.

The work to identify business risk involves the identification of the risks that may arise during the conduct of an activity (still to be covered) and to determine their characteristics. The risks identification aims both the exposure of the property, of the rights and human resources and the potential hazards that may cause these exposures. The risks identification is accomplished in two stages: the risk perception, namely the awareness that a risk threatens the business project and the identification of the risk itself. The risk categories the most commonly used are:

- technical risks: quality or performance, dependence on homologated technology, the requirement to obtain a certain performance;

- project risk management: misallocation of time and resources, inadequate quality of the project plan, unrealistic or incomplete estimations, supply problems, poor communication techniques;

- internal risks: the costs, time and goals are inconsistent, a lack of prioritization between the organizational projects, an inadequate or discontinuous funding, conflicts in funding or wrong resources allocation to different projects of the organization;

- $\quad$ external risks: changes in legislation, market trends, labor disputes, country risks.

\section{Study on the main environmental risk factors which influence the SMEs from the North East region, Romania. Case study on the industrial SMEs} The business risks assessment can be done by estimating two dimensions: (Böcker, K., 2008).

Impact: It measures the impact of each risk and refers to the importance of the probable loss. Values are given on a scale from 1 (negligible impact) to 4 (very high impact).

Probability: this establishes the possibility of occurrence of the event on a scale of 0 to 1.

In the evaluation process, there are four categories of business risks:

- $\quad$ Strategic risks: These are risks that affect the company values and it can lead to bankruptcy, stagnation or fall in activity as a result of the inability of the organization to adapt itself to a specific competitive, constantly changing environment; these are specific risks including changes in customer priorities, threats from the traditional competitors and emerging changes in the brand perception, changes in the access to financial capital, to the human capital, new developments in technology, the global movement of the economic and geo -political factors, legal changes and regulation, quite numerous in the current economy;

- Economic risks: These risks include changes in the interest rates, in the exchange rates, commodities, shares and other property, in credit and other liquidity risks; 
- Operational risks: There are risks related to key people and their career planning, the composition and the orientation of the Board of Directors, the orientation of the human resources and employment, information technology systems, accounting, auditing and control systems, regulatory compliance, design errors, productivity and disruptions in operations and supply chain;

- Hazard Risks: the risk that determines the decrease of the non-financial assets because of the natural phenomena, physical damage of the real assets, the employees' actions, events that affect the liability, the product revocation and integrity, as well as the business interruption.

In order to assess and accomplish an efficient risk management, both the small and medium organization and its managers must learn to approach the risks in terms of a holistic view and subsequently, to reduce the internal and/or external financing risks. (Terry et al., 2001).

The methods were based on the interpretation of the opinions and attitudes as results of a questionnaire survey, a systematic observation of the concrete phenomena and synthesis of some previous studies in this area.

The analysis of the level of preparedness of small and medium companies for the risk management was performed using as the basis a questionnaire for gathering information with a number of 110 questions, the bimodal format (Yes/No) addressed to key people (manager / responsible). By using of special computer applications afforded we obtained compliance rates for each category of risk and a risk general rate. The performances evaluation in the obtained results aimed to identify the following risks: financing risks, Branding and good reputation risks, Corporate governance Behavioral risks and safety, Ergonomy and accidents management/ losses/ employer responsibility, Absences management, Environmental management, Producer's responsibility, Property conservation, Business continuity, Computer dependence, Erisks and Internet, Human resources, Key employees, Political and credit risks.

Finally, we calculated an overall score (average weighted by the importance given to each category of risk) to see how the companies are able to manage the risks they face. To calculate the risk score of each topic, there were used different weights, given to each question in the survey, according to the extent considered appropriate to each question for the study in question.

The method used in this paper work is based on a questionnaire to a sample of 120 top managers of the SMEs in the NE region, coming from the industrial activity, operating on the market for more than two years. The management of information and the data collection was conducted in the early 2013.

The main objectives of the present study were:

- What are the operational risks the managers coming from the analyzed SMES recognize;

- Which is the evolution of the turnover of these companies, influenced by the identified risks;

- What are the strategies for the future in these SMEs;

The major objective of this research was to identify the internal and external major factors which influence the present activities and the future of the SMEs from the North East region in Romania.

Both in Romania and the EU's countries, the SMEs are defined to be those companies that have up to 250 employees and generate a net turnover of 50 million Euros. At the EU level, there are over 23 million SMEs (a figure recorded in 2011), which represents over $98 \%$ of all the European enterprises (http://ec.europa.eu/enterprise/policies/ sme/facts-figuresanalysis/performance-review/files/countries-sheets/2010

2011/romania_en.pdf.). In terms of their contribution to employment, the SMEs bring $67.4 \%$ of the existing jobs in the non-financial economy, inside the European Union, in 2012, virtually maintaining the same level as in 2011 (67.4\% ), but greater than 2010 
(66.9\%). The share of gross value added of the SMEs suffered a slight decline in the last two years, falling to an average of $58.1 \%$ of the aggregate E.U.'s economy.

Romania is well below the European average, concerning the development of the SMEs sector. If the European average amounts to 42 SMEs/1000 inhabitants, in Romania there are around $24 \mathrm{SMEs} / 1000$ inhabitants. According to a recent report made up by the World Bank (Doing Business Report, 2013), Romania is positioned on the 68th place in the world range of countries, in terms of the facilities for setting up a company (a business start-up). Even in such difficult conditions, between 2003 and 2008, there was a significant increase of the number of the Romanian SMEs. Then, a period of decline followed, between 2008 and 2012 and the number of such enterprises began to decrease. The economic crisis overlapped with an unstable economic framework and generated a cessation of activity, in less than two years, for about 250,000 SMEs in our country. Looking at the data from the graphic 1, it can be concluded that a substantial fraction of SMEs in Romania (52.30\%) have faced some difficult problems in 20082012, because of the national and European economic decline. These firms are more vulnerable to contextual challenges than the large firms and only a percentage of $34.51 \%$ reported a substantial increase in their activity.

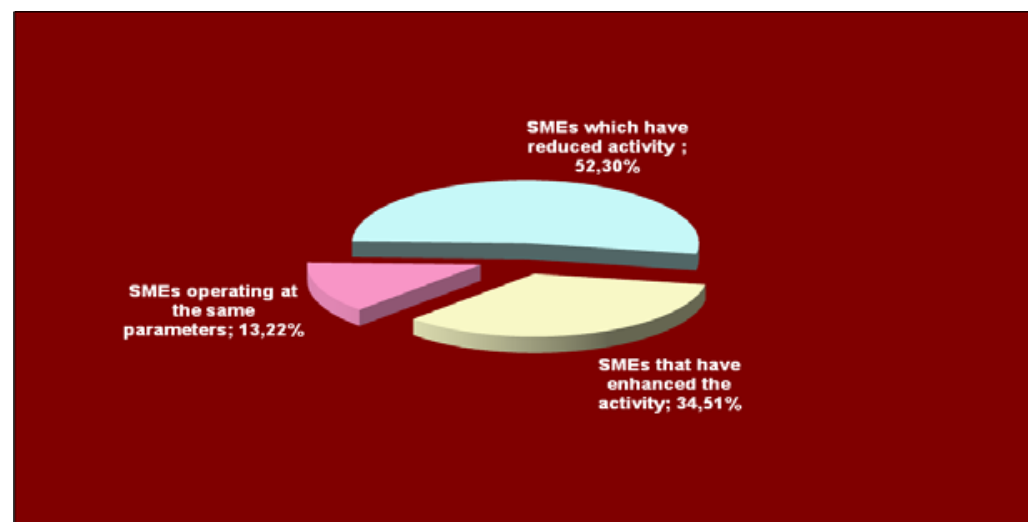

Graphic 1. Dynamics of the surveyed SMEs between 2008 and 2012.

Source: adapted to the data from the SMEs White Book, 2012, Sigma House of Publishing, Bucharest

In 2010, 13,846 small and medium enterprises offered jobs for 53,120 employees. In 2008-2010, suffering from the impact of the global economic and financial negative trends, the SMEs in this region experienced a downward trend. The largest decline was registered in the field of the construction industry and in trade. In 2010, the turnover of these companies decreased, compared to 2008, by approximately $30 \%$. The unemployment rate, in 2009, stood at around 9\%, almost double compared with the rate registered in 2007.

\section{Results and discussions}

The economic and the financial performances of these SMEs, in the present and for the future, must be analyzed taking into account some uncertainties and business risks and by the means of the activities that these companies intend to put into practice to fight them.

According to a survey conducted in 2012 by the National Council of the SMEs in Romania, about $54 \%$ of respondents, as Romanian small entrepreneurs, considered the current business environment as to be not favorable to the business development. This 
study revealed that the main difficulties faced by the Romanian SMEs, in 2011, as they were the following: the decreased domestic demand, the excessive taxation, excessive bureaucracy, the inflation, corruption etc. It should be noted that the embarrassing conditions that affects the activity and economic performance of these companies are, as follows:

- $\quad$ decline in the domestic demand;

- $\quad$ excessive taxation;

- bureaucracy;

- excessive controls;

- $\quad$ high borrowing costs;

- delays in cashing invoices from the private companies;

- corruption;

- inflation;

- difficult access to credit;

- $\quad$ recruiting, training and motivating staff;

- relative instability of the national currency;

- $\quad$ non-payed invoices by the state institutions;

- increasing wage costs;

- $\quad$ poor quality of the infrastructure ;

- competition made by the imported products;

- $\quad$ decline in the export demand;

- obtaining necessary consultancy and training company;

- $\quad$ knowledge and adoption of the Communautaire acquis.

Another survey, conducted by the National Council of the SMEs, among the Romanian small entrepreneurs, underlines that about half of them does not predict any activity, rather do not elaborate short, medium or long term business strategies. However, the small and medium firms in Romania are ranked as to be the second in the central and eastern region of Europe, in terms of optimism, linked to the effects of the financial crisis, after the Austrian ones. Thus, most of the small entrepreneurs from Romania intend to expand its business, in a moderate manner, in the near future (C.N.I.P.M.M.R., (2012), 2012, Cartea Albă a IMM-urilor din România, The SMEs’ White Book).

In the first stage of our inquiry, a total of 35 risks was identified. The evaluation results using the probability and the impact of the identified risks, based on questionnaires and by processing information from the documentation provided by the managers of SME taken under the analysis, are shown in Table Risk Assessment. (see table 1).

Table 1. Table Risk Assessment

\begin{tabular}{|c|l|c|c|c|c|c|}
\hline & risk description & risk type & $\begin{array}{c}\text { impact } \\
\text { factor } \\
{[1-4]}\end{array}$ & $\begin{array}{c}\text { probability } \\
{[0-1]}\end{array}$ & $\begin{array}{c}\text { risk } \\
\text { factor }\end{array}$ & priority \\
\hline $\begin{array}{c}\text { Strategic } \\
\text { risk }\end{array}$ & $\begin{array}{l}\text { The occurrence } \\
\text { of some } \\
\text { unforeseen risks } \\
\text { in the general } \\
\text { strategy of the } \\
\text { company, } \\
\text { because of a lack } \\
\text { of a risk strategy }\end{array}$ & Strategic & 2 & 0,80 & 1,60 & \\
\hline
\end{tabular}




\begin{tabular}{|c|c|c|c|c|c|}
\hline $\begin{array}{l}\text { The risk of } \\
\text { major } \\
\text { fluctuations } \\
\text { in prices }\end{array}$ & $\begin{array}{l}\text { The impact on } \\
\text { the company's } \\
\text { significant } \\
\text { variations in } \\
\text { prices and } \\
\text { quantities of the } \\
\text { raw materials }\end{array}$ & Economic & 1 & 0,50 & 0,50 \\
\hline $\begin{array}{l}\text { The risk of } \\
\text { disputes }\end{array}$ & $\begin{array}{l}\text { Suing the } \\
\text { company for } \\
\text { various reasons }\end{array}$ & Strategic & 2 & 0,50 & 1,00 \\
\hline $\begin{array}{c}\text { Economic } \\
\text { environment } \\
\text { risk }\end{array}$ & $\begin{array}{l}\text { Risks due to } \\
\text { changes in the } \\
\text { local, national } \\
\text { and European } \\
\text { economic } \\
\text { environment }\end{array}$ & Economic & 2 & 0,60 & 1,20 \\
\hline Credit risk & $\begin{array}{l}\text { Major financial } \\
\text { risks because of } \\
\text { macroeconomics } \\
\text { changes }\end{array}$ & Economic & 2 & 0,35 & 0,70 \\
\hline $\begin{array}{l}\text { Funding } \\
\text { risk }\end{array}$ & $\begin{array}{l}\text { Risks from the } \\
\text { lack of a long- } \\
\text { term strategy on } \\
\text { financing risk }\end{array}$ & Strategic & 2 & 0,50 & 1 \\
\hline $\begin{array}{l}\text { The } \\
\text { property } \\
\text { risk }\end{array}$ & $\begin{array}{l}\text { Risk due to } \\
\text { possible disputes } \\
\text { regarding the } \\
\text { property }\end{array}$ & Operational & 2 & 0,05 & 0,10 \\
\hline $\begin{array}{c}\text { Risk } \\
\text { contestation } \\
\text { procedures }\end{array}$ & $\begin{array}{l}\text { Risks due to the } \\
\text { failure in the } \\
\text { organization and } \\
\text { analysis of the } \\
\text { employees' and / } \\
\text { or customers } \\
\text { 'complaints }\end{array}$ & Operational & 2 & 0,40 & 0,80 \\
\hline $\begin{array}{l}\text { Competition } \\
\text { risk }\end{array}$ & $\begin{array}{l}\text { Risk due to the } \\
\text { increased } \\
\text { competition and } \\
\text { because of the } \\
\text { lack of a } \\
\text { competition } \\
\text { continuous } \\
\text { monitoring }\end{array}$ & Strategic & 1 & 0,50 & 0,50 \\
\hline
\end{tabular}

Risks in the red zone should be resolved first because they are the ones that can create great difficulties and are critical for the small firm, while the green zone have the lowest priority, as they are minor risks. The interviewed managers have appreciated that the occurrence of some unforeseen risks in the general strategy of the company, because of a lack of a risk strategy may be a critical risk, with a probability of 0.80 and an impact factor 2, while some significant risks, such as environmental economic risk, prices risk, funding risk, credit risk, competition risk, coming from the changing environment, have 
a low risk for our managers, with probabilities between 0.8-1.2, and impact factor 2 . There are some comments to make about the managers' economic education and their capacity to understand and face the business risks.

The compliance rate for each chapter of the identified risk by the questionnaire is shown in Table 2. Chapters such as "Environmental Management" and "Producer's Responsibility" had the highest rate (100\%), while chapters "Key employees" and "Human Resources" know the lowest rates (30\% and 33\%).

Table 2. The calculated scores by the questionnaire, for each chapter of risk

\begin{tabular}{|c|c|c|l|}
\hline Chapter (type) of risks & Score & $\begin{array}{c}\text { The } \\
\text { highest } \\
\text { score }\end{array}$ & \multicolumn{1}{|c|}{$\%$} \\
\hline The financing risks & 400 & 1100 & $36 \%$ \\
\hline Branding and good reputation risks & 800 & 1200 & $67 \%$ \\
\hline Corporate Governance & 300 & 700 & $43 \%$ \\
\hline $\begin{array}{c}\text { Behavioral risks and protection } \\
\text { safety }\end{array}$ & 1650 & 2000 & $83 \%$ \\
\hline $\begin{array}{c}\text { Ergonomy and Accidents } \\
\text { Management/Losses/Employer } \\
\text { responsibility }\end{array}$ & 550 & 600 & $92 \%$ \\
\hline Absences Management & 650 & 700 & $93 \%$ \\
\hline Environmental Management & 900 & 900 & $100 \%$ \\
\hline Producer's Responsibility & 400 & 400 & $100 \%$ \\
\hline Property Protection & 950 & 1100 & $86 \%$ \\
\hline Business Continuity & 400 & 500 & $80 \%$ \\
\hline Computer Dependence. E-risks and & 750 & 1100 & $68 \%$ \\
\hline Internet & 200 & 600 & $33 \%$ \\
\hline Human Resources & 300 & 1000 & $30 \%$ \\
\hline Key employees & 200 & 400 & $50 \%$ \\
\hline Political and credit risks & & \\
\hline
\end{tabular}

The overall score - calculated as a weighted average based on the importance given by the evaluator to each chapter in question - is set to $67.7 \%$, and is considered a good value which denotes the capacity above average of the SMEs for risk management faced by the analized companies.

The score of each risks chapter is colored according to the system for comparison of the scores method. It must be remembered that this rate is based only on a percentage score, so the criticality of each category should be evaluated based on the financial impact on business operations. However, it is recommended that all the questions in each category, regardless their importance, should be considered as potential mitigation recommendations for the future. 


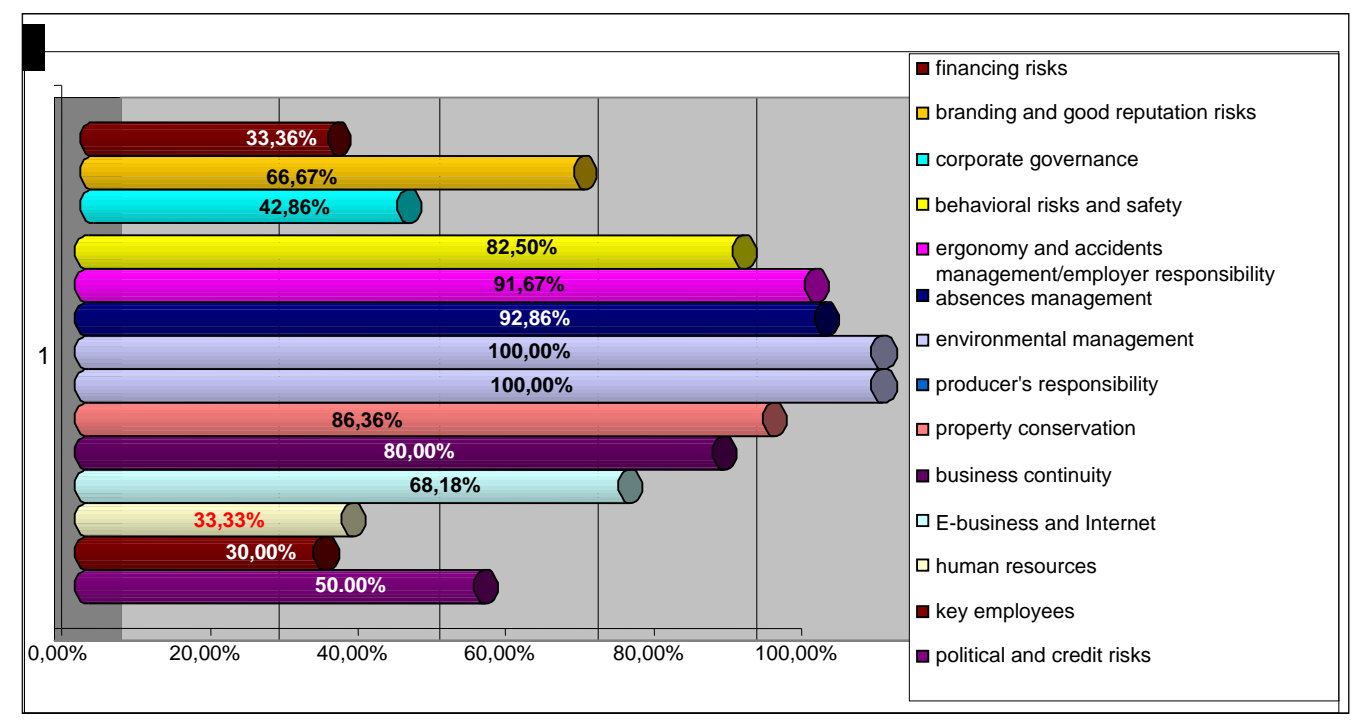

Fig. 1. The calculated scores for the topics in the questionnaire.

\section{Colors for each chapter (type) of risks}

\begin{tabular}{|l|l|}
\hline The financing risks & \\
\hline Branding and good reputation risks & \\
\hline Corporate Governance & \\
\hline Behavioural risks and safety & \\
\hline $\begin{array}{l}\text { Ergonomy and Accidents Management/Losses/Employer } \\
\text { responsibility }\end{array}$ & \\
\hline Absences Management & \\
\hline Environmental Management & \\
\hline Producer's Responsibility & \\
\hline Property Protection & \\
\hline Business Continuity & \\
\hline Computer Dependence. E-risks and Internet & \\
\hline Human Resources & \\
\hline Key employees & \\
\hline Political and credit risks & \\
\hline
\end{tabular}

Legend 


\section{Financing Risk}

The score for this risk chapter is $37 \%$. This score represents a fairly low rate, as a warning, indicating that financing risk is a subject that requires more attention paid by the managers of the SMEs. The main advantage in terms of risk financing that results from the questionnaire is that the company has a proactive policy in insurances strategy, which is reviewed at relatively short intervals, allowing for some rapid reaction to changes coming from the internal and external environment of the firm. However, this strategy lacks a longer time horizon, which gives it a weakness against future risks distant in time. Fluctuations in the prices and quantities of commodities and currency have a significant, but not very big on the business activity, which increases the need for risk financing. The adoption of financial procedures to minimize exposure to such fluctuations would significantly reduce the size of these types of risks. At the same time, non-adopting a system of total cost of risk leads to over / under-sizing costs allocated to long-term financial risk. Most of these weaknesses have as the primary source the lack of a budget allocated to risk management.

\section{Branding and reputation risk}

The achieved score in this risk chapter is $67 \%$. The reputational risks are very important to a company which, while working in the private sector, is listed on the stock market or has penetrated a new market If the company's reputation is in danger, the consequences can cause a disaster through loss of the customers' confidence and the protection by the means of insurances is difficult for this type of risk. The business operations require close attention and a factual analysis in order to estimate the potential consequences. This risk chapter has a relatively high score due the attention to own image, which is reflected in the activities of the marketing department and its financial support, including copyright and media monitoring of a direct relevance for the company. Making a financial assessment of the main official brand company product, alongside with the adoption of different ways of measuring the brand performances would increase the score of this risk chapter and would reduce the risk of reputation.

\section{Corporate Governance}

The score in this section is $42.86 \%$, primarily due to the lack of training programs for stakeholders regarding the risk management and the poor developed information system to identify the key risks and their causes. The companies maintain a relative control of the risk at the level of senior managers, although there is a full and comprehensive implementation of the risk management process. As the implementation an integrated risk management will start and continue the effects will be beneficial in the long term. This enhances communication within the company on key risks and possible losses, with financial consequences and facilitate the alignment with the company goals and the overall vision, an aspect appreciated by us as being deficient. Within the organization, the managers wants to maximize and ensure long-term profit, by taking account of risk. This objective is the major responsibility of the General Manager of the organization. Because the risk plays an important role in achieving this objective, the General Manager or the Executive Director may be labeled as "final” risk managers and therefore, it is not unusual that the risk responsible inside the organization respond directly to the Director General.

\section{Behavioral Risks and Safety}

The score for this risk chapter is $82.50 \%$. Even if the score is high there are some important risks in this regard.

The behavioral risk analysis is very important because in the recent years the companies has been involved in a reorganization without taking into account explicitly the impact on employees' behavior. The factors that lead to behavioral risks that may affect the companies performances were only partially identified. There are a few methods of evaluating the effectiveness of operational procedures. 
Certain elements of awareness for the workplace risks and the risk reduction program are:

- The review and the analysis fo the accidents causes;

- The review of the potential risks at work;

- Identify and eliminate risk;

- An analysis for the probability and severity of risks;

- Advising.

- Ergonomics and accidents management / losses/ employer's responsibility.

- The score for this chapter is $91.67 \%$, which is among the largest registered by the company.

An effective ergonomic program should be able to demonstrate improvements in manual handling (or ergonomic improvements documented in other fields of activity) and reduces accidents caused by physical demands. This can be demonstrated by changing instruments, tools, changing workplaces, etc. leading to a reduction of the accidents before the implementation. One field where progress is needed is the correct management of the employees' complaints. The importance of this chapter is justified given the serious challenges facing the Northeastern region in finding and retaining the qualified staff cause of the massive migration of labor in the more developed countries of the European Union.

\section{Absences management}

The score is $92.86 \%$, its high rate appeared under the existence of developed programs for the evidence of absences inside the companies. The lack of any strategy in absences management caused by health reasons however leads to the existence of a factor risk in this area that the companies would have to eliminate.

\section{Environmental management}

The score of $100 \%$ in this chapter, which demonstrates that environmental issues are considered to be an important priority in the company's vision, so they seek for sustainable development.

The existence of an official policy on the environment, managed by responsible managers leads to a high degree of uncertainty and risk fighting, in case of the environmental accidents that might occur during the current activities. In the context of high environmental concerns arising from the Romania's integration in the European Union this topic can be an advantage, when the SMEs will try to access the structural and cohesion funds for business development and economic competitiveness.

\section{Producer's responsibility}

The score for this risk chapter is $100 \%$.

Most of the points of this chapter are mandatory responsibilities, assumed by the companies, to comply with the European rules, introduced when Romania has been accepted as a member of to the European Union. The continuation of the present way of doing things will maintain a low risk in the field. Companies' management should pay a continuous attention but, still, this risk chapter stands frequent changes in the regulations.

\section{Risk of property protection}

The score for this risk sector is set at $86.36 \%$ as a result of the nine responses for questions in this section. The available property protection measures are vital to support the activity. Considering this aspect, the properties are considered critical to company, that is why it has a complex system of the property protection, periodically evaluated, and modeled on the new risks arising in this critical area. Risks that the company may encounter in this area are listed below:

- $\quad$ Fire and natural hazards such as earthquakes, floods, storm, lightning, etc.;

- Theft and intentional acts, such as fire, terrorism, bomb threats, etc.;

- $\quad$ Failure of machinery and electronic equipment; 
- Employees' and third parties' accidents, either as visitors or contractors. Business discontinuity and counteracting the risk of discontinuity

Considering the current approach of the business in the analyzed companies, the existence of a business continuity plan becomes essential. The score this risk chapter is $80 \%$, which is above the average and it requires a special attention. A business continuity plan should include emergency responses, crisis management procedures, and communication and recovery strategies.

Preparing a business continuity plan is mainly aimed to reduce the impact of service interruption, regardless of the source generating the interruption and the resumption of the main functions of the organization, which is planned by identifying the necessary period to recover for the critical functions.

\section{Computer dependence risk, E-risks and Internet}

The outcome score is $68.18 \%$ under this risk chapter. The improvement of this score is considered to be necessary, due to the rapid expansion of the field of virtual trading of various goods and services at the national and European level. A special attention should be paid to such risk assessment, to the IT training for the personnel, regarding emergency situations in the field, using the Internet as a way of selling their products and implement safety procedures, by exploiting these opportunities

\section{Human Resources}

The score is set at $33.33 \%$ for this risk chapter. This value is below the average so it requires a special attention for the management of human resources. There are many risks in this section, where the most important are generated by the events of the last period in the activity of SMEs, including a large number of layoffs and reduced periods of activity The need to counter these types of risks should be analyzed as soon as possible as the involved human resources continue their work of in optimal conditions.

\section{Key employees}

The rate for this risk section is $30 \%$. According to Human Resources Department, the key people are identified, but the strategy to cope with a loss of key employees is nonexistent. Another important issue in order to solve the problems related to the financing of key employees is the recruiting for a substitute. The funds for the headhunting a successor must be in managers' attention. In addition, managers have to pay higher wages if it will be necessary to recruit a new employee in the case of loss in key personnel

\section{Political and credit risk}

The score is set at $50 \%$ for this risk chapter, which is mainly due to one of the critical risks of the companies, namely counterparty risk, where the companies have a revenue collection problem. The credit insurance is insufficient to fight against the very high degree of risk in this area, so that more radical and complex measures are necessary for a risk minimization. In recent years, the problems with the exportation have contributed to reduce this score.

One of the most important challenges for the establishment, the growth and the survival of SMEs' remains their access to funding. Though they provide $50 \%$ of the jobs in most developed countries, the SMEs attract only a very small percentage of the total investments. The investments in the SMEs for the G20 are 574 billion, representing 6\% of the total 9.250 billion in all the forms of investment and the vast majority of the funds are coming from the bank lending.

Only $17.5 \%$ of the Romanian think to initiate a business perspective on their own within 6 months. This percentage puts our country on the 56th position of 59 evaluated countries and ranked it on the last position among the countries with efficiencyoriented economy. A percentage of almost a half (45.99\%) of the adult population of Romania avoids to start up a new company for fear of a possible financial failure.

According to certain analysis and reports, the SMEs sector in the Bacau County recorded a slight recovery in 2011 and 2012. Thus, although in 2011 the number of the 
SMEs has declined by over $4 \%$ compared to 2010, the turnover of these SMEs increased by $17 \%$ compared to 2010 , while their gross profit grew by over $40 \%$ compared to 2010. The number of employees working in the SMEs sector, in this department of the country, increased also, by almost $6 \%$ compared to same period of 2010.

So, the vulnerabilities of the SMEs are mainly linked to the limitation of the necessary resources, to the entrepreneurs' financial decisions, to the changing business environment and to the fragile training for facing the various business risks.

Productivity and profitability of SMEs reveals the precarious situation of the SMEs in Romania, in terms of efficiency and competitiveness.

\section{Conclusions.}

As a final conclusion, the SME sector in Romania is far to be a solid and competitive segment of the national economy. In order to embed the SMEs sector in Romania there is a need for a more rigorous approach, based on the implementation of business and risks management strategies.

Risk management is not an exact science, it is an art of approximation, whose quality increases with time and the spent capital. The small and medium companies do not have their history of risk management, so it is recommended to introduce integrated future investment in information systems for risk management and train the employees in the integration of risk management to enhance their work efficiency.

\section{References}

Böcker, K. (2008), Modelling and Measuring Business Risk, Pillar II in the New Basel Accord - The Challenge of Economic Capital.

C.N.I.P.M.M.R., (2012), The SMEs' White Book, Editura Sigma, Bucureşti, http://www.cnipmmr.ro/.

Comisia naţională de prognoză, (2012), The SMEs contribution to the economic growth - present and future, http://www.cnp.ro/inovatie/docs/seminar-studii-24-022012/prezentare_studiu _3.pdf; http://www.insse.ro.

European Commission (2011), Small Business Act Fact Sheet 2010/2011 Romania, http://ec.europa.eu/enterprise/policies/sme/facts-figures-analysis/performancereview/files/countries-sheets/2010 2011/romania_en.pdf.

European Commission (2012), Small Business Act Fact Sheet 2012 Romania, http://ec.europa.eu/enterprise/policies/sme/facts-figures-analysis/performancereview/files/countries-sheets/2012/romania_en.pdf.

International Bank for Reconstruction and Development/The World Bank (2012), Doing Business Report 2013 - Smarter Regulations for small and medium - size enterprises, http://www.bnr.ro/, http://www.doingbusiness.org/reports/globalreports/doing-business-2013.

Terry, C.; Webb, M.; Griffith, M. (2001), The Risk Factor. How to Make Risk Management Work for You in Strategic Planning and Enterprise, England, Harrogate. 